\title{
Design of Integrated Agro-Tourism Business Ecosystem (Case Study in Batu)
}

\author{
Arman Hakim Nasution ${ }^{1}$, Dewie Saktia Ardiantono ${ }^{1 *}$, Ninditya Nareswari ${ }^{1}$, Ribka Anintha \\ Miyagi ${ }^{1}$, Aang Kunaifi ${ }^{1}$ \\ ${ }^{1}$ Department of Business Management, Institut Teknologi Sepuluh Nopember, Surabaya, Indonesia \\ *Corresponding author. Email: dewie@mb.its.ac.id
}

\begin{abstract}
The tourism industry and the agricultural industry are the main economic pillars of Batu City. The concept of Agrotourism was promoted to collaborate these two potential industries. Thus, this study proposes a business ecosystem design for integrated agro-tourism. However, agro-tourism will also contribute to the amount of waste that affects environmental conditions in Batu City. The circular economy concept can solve the waste generated by integrating agro-tourism in Batu. To design a business ecosystem, researchers first analyze the potential for the application of integrated agro-tourism. Then the researcher conducted a Stakeholder Mapping analysis to determine which stakeholders were involved in the integrated agro-tourism business ecosystem. Analysis of external conditions is also carried out using the PESTLE framework, which consists of Political, Economic, Social, Technological, Legal, and Environmental. After that, the business ecosystem design was carried out, which resulted in the core business, extended enterprise, and business ecosystem.
\end{abstract}

Keywords: Agro-tourism, Business Ecosystem, PESTLE Analysis, Stakeholder Mappin.

\section{INTRODUCTION}

The tourism industry and the agricultural industry are the main economic pillars of Batu City. The concept of Agro-tourism was promoted to collaborate these two potential industries. Research for agro-tourism design models is applied to design business ecosystem designs suitable for implementation in the agro-tourism sector. This research will design a business ecosystem design in an agro-tourism in Batu.

Specifically, the researcher also wants to analyze how the business ecosystem for agro-tourism in Indonesia should be based on a circular economy. The application of a circular economy is considered capable of being a solution to the large amount of waste found in Indonesia. This circular economy has started to become a trend in Indonesia, considering the government's plan to reduce the volume of waste by 30 percent and reprocess 70 percent of Indonesia's waste by 2025 [1]. However, the problem occurs when the government and those responsible for processing waste do not synergize appropriately. On the other hand, waste processing is carried out only by a few informal parties who have limited processing capacity. So, it is necessary to have a collaboration called ABGS collaboration, which means cooperation between academic institutions (Academic), the business sector (Business), government (Government), and society (Society).

To achieve tourism sustainability, not only certain parties are responsible for working on this sustainability. Integration takes a design that can map which parties and each stakeholder's roles to work together to achieve the sustainability goals for Indonesian tourism in the next five years. In Indonesia, the trend of agro-tourism shows positive growth. It is expected that agro-tourism can be used as an object of guidance for other forms of tourism for the application of the concept of sustainability. However, there is still a lack of research on a suitable and healthy business ecosystem for the agro-tourism industry that applies the circular economy concept. The creation of this business ecosystem also needs to be aligned with the business model's redesign. A methodology is required as a reference in translating the ecosystem business into a business model.

\section{LITERATURE REVIEW}

\subsection{Agro-tourism Industry}

Agro-tourism is a form of the agricultural sector's creative economy that can provide added value to improve farmer welfare. Agro-tourism can be said to be a combination of agriculture and tourism. Agrotourism activities aim to increase experience, knowledge, and recreation related to agriculture.

There are three criteria for agro-tourism areas[2]:

1. Has potential or regional basis in the agro sector, be it agriculture, horticulture, fishery, or livestock

2. The existence of community activities dominated by agricultural and tourism activities with high linkages and dependencies, including agricultural activities that encourage the growth of the tourism industry, and vice 
versa, tourism activities that spur the development of the agricultural sector.

3. There is an intensive and mutually supportive interaction between agro-activities and tourism activities within the area, including various tourism activities and products that are developed sustainably.lored as they had difficulties in funding, marketing, and labors.

\subsection{Business Ecosystem}

A business ecosystem describes the structure and behavior of a network of high-tech organizations that share a key technological platform and the ways individual firms can flourish in such an environment" [3]

\section{RESEARCH METHODOLOGY}

This study uses a design thinking framework approach to formulate a business design for an integrated tourism ecosystem based on the circular economy in Batu agro-tourism. The stages of analysis used in this study include:

1. Analysis of the potential market for implementing integrated tourism in Batu Agro-tourism.

At this stage, interviews were conducted with the Batu City Tourism Office to identify the potential for implementing integrated tourism in Batu City Agro-tourism. There are several results obtained from the interview process, including the sector of choice for implementing the circular economy, the results of market identification for processed products from the circular economy, and the expected marketplace planning.

2. Stakeholder mapping is used to understand how the strength and urgency of each stakeholder [6] towards integrated tourism in Batu Agro-tourism.

3. PESTLE Analysis

This model allows researchers to identify various issues related to politics, economy, social, technology, law, and the environment[7].

4. Business Ecosystem Design

There are three stages in the Business Ecosystem, namely Core Business, Extended Enterprise, and Business Ecosystems. In this study, researchers will focus on the core business of Integrated Agrotourism in Batu City.

\section{ANALYSIS AND DISCUSSION}

Based on the interview results, it was found that 4 (four) sectors would be the focus for implementing the circular economy in Batu City. The first focus sector is the agribusiness sector. This sector is one of the sectors that drive the economy in Batu. The second sector, which is used as the focus of implementation, is the livestock sector. This sector was chosen because the waste generated by livestock is quite significant. However, the livestock sector has great potential for economic development in Batu. The next sector is the herbal plant sector, which is gaining popularity among customers and tourists. Another sector is the fisheries sector which also shows its existence at the local market and national markets.

The mapping of market groups from each sector is shown in Figure 1. Based on Figure 1, the product that can be sold locally is freshwater fish currently being sold around Malang Raya. Meanwhile, products that can be sold nationally include ornamental fish, cows (beef and cow's milk), and goat (goat meat and dairy). Then, from the agricultural sector, some products can be marketed internationally, namely potatoes, garlic, and peas.

The Stakeholder mapping can be seen as follows:

\begin{tabular}{|l|l|}
\hline High Influence, Low & High Influence, High \\
Interest & Interest \\
- Walikota Batu & - Herbal Products \\
- Bappeda Batu & Tourism Village \\
- Dinas Pertanian & - Livestock and \\
- Dinas Peternakan & Agricultural Tourism \\
& Village \\
& - Plasma system \\
& investors \\
& - Batu City Tourism \\
& Office \\
& - Local Tourist \\
& - Landfills \\
\hline Low Influence, Low & Low Influence, High \\
Interest & Interest \\
- Dinas Perindustrian & Dinas Lingkungan \\
dan Perdagangan Kota & Hidup \\
Batu & \\
- International Tourist & \\
\hline
\end{tabular}

The results of the PESTLE analysis are as follows:

\begin{tabular}{|c|c|}
\hline Aspect & Description \\
\hline Political & $\begin{array}{l}\text {-There is already an incentive in } \\
\text { the form of a subsidy for organic } \\
\text { farmers. }\end{array}$ \\
\hline Economic & $\begin{array}{l}\text {-A tourism village's economic } \\
\text { potential is obtained from the } \\
\text { production process that has been } \\
\text { carried out, but also from tourism } \\
\text { potential (especially educational } \\
\text { tourism). }\end{array}$ \\
\hline Social & $\begin{array}{l}\text {-The social situation in each tourist } \\
\text { village has improved where each } \\
\text { member of the village is aware } \\
\text { that the village's existence as a } \\
\text { tourist Village can provide } \\
\text { economic benefits. }\end{array}$ \\
\hline Technological & $\begin{array}{l}\text {-The production tools used today } \\
\text { are generally traditional means of } \\
\text { production. }\end{array}$ \\
\hline Legal & $\begin{array}{l}\text {-The circular economy has not } \\
\text { become the Key Performance } \\
\text { Indicator of the Batu City Tourism } \\
\text { Office. }\end{array}$ \\
\hline Environmental & $\begin{array}{l}\text {-In various tourist villages, both } \\
\text { agriculture and livestock, waste is a } \\
\text { problem that is currently being the } \\
\text { focus to be resolved by the relevant } \\
\text { agencies. }\end{array}$ \\
\hline
\end{tabular}




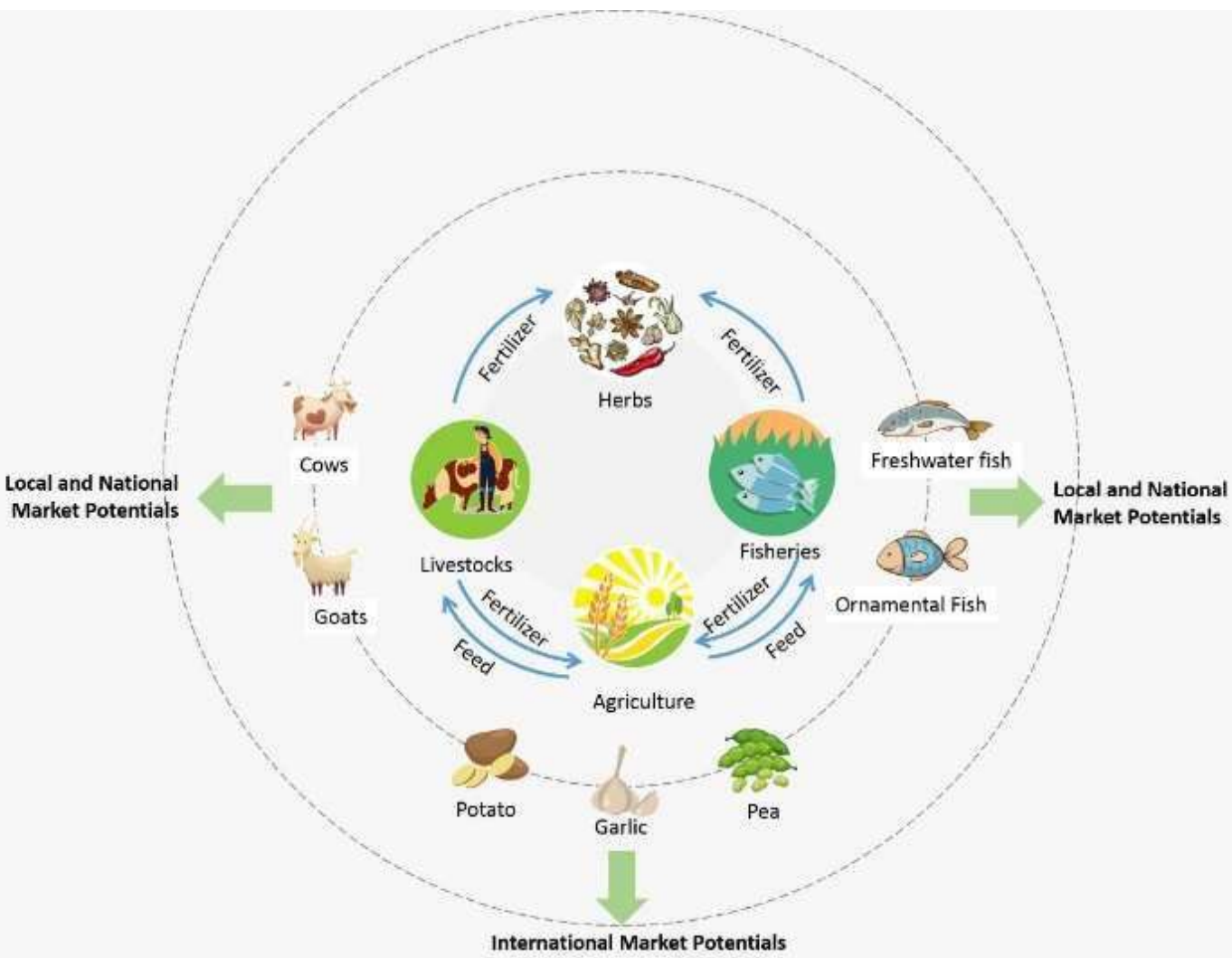

Figure 1 Identify the market for the product

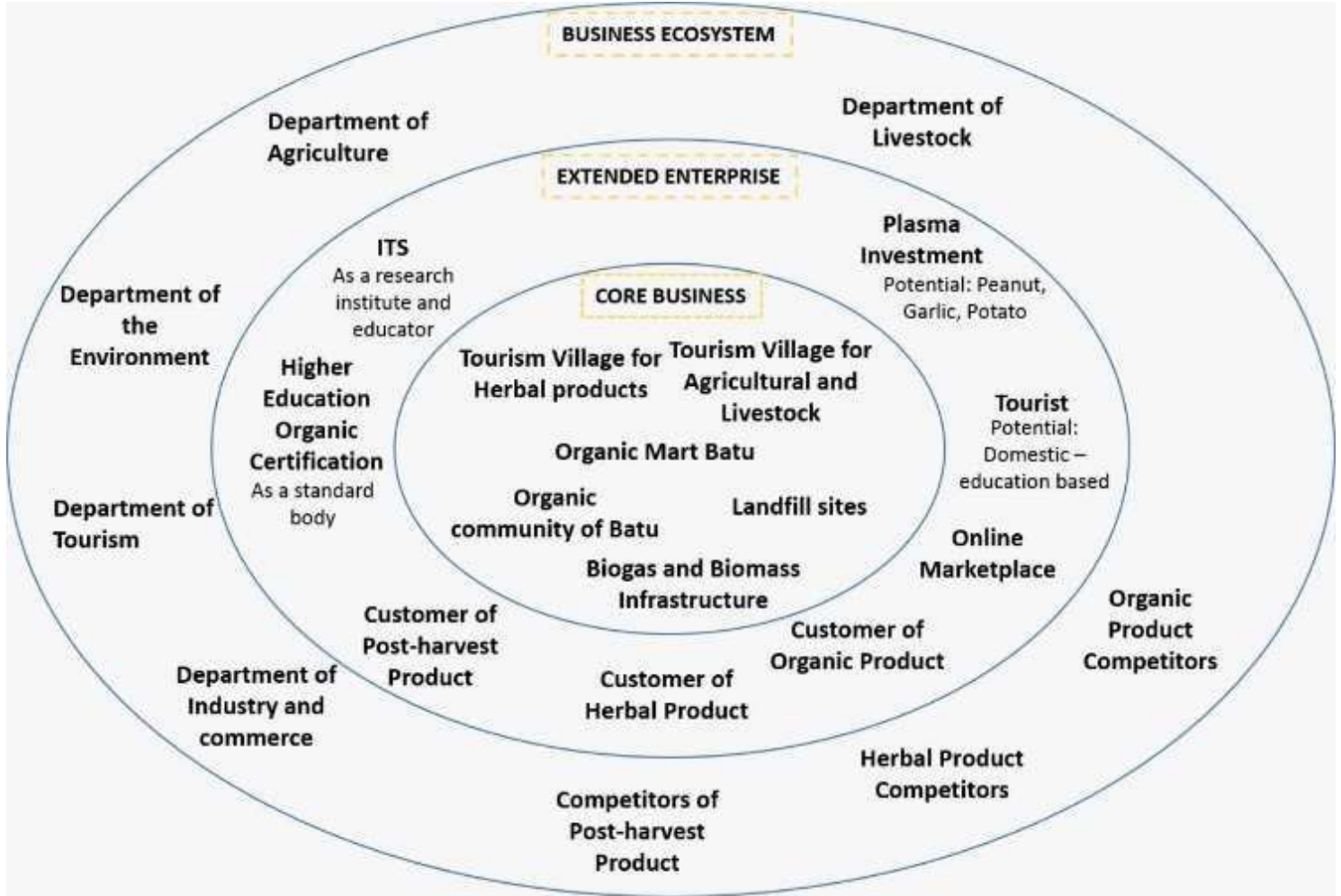

Figure 2 Business Ecosystem Design 
There are three stages in the Business Ecosystem, namely Core Business, Extended Enterprise, and Business Ecosystems. In this study, researchers will focus on the core business of Integrated Agro-tourism in Batu City as seen in Figure 2.

\section{CONCLUSION}

This research is the first step in designing a Business Ecosystem of Integrated agro-tourism in Batu City. Furthermore, it is necessary to make detailed integration designs between agriculture, livestock, fisheries, agrowaste, and tourism waste in forming a circular economy. It is also required to develop a city government policy design to support the implementation of a circular economy in agriculture, livestock, fisheries, agro-waste, and tourism waste.

\section{ACKNOWLEDGMENT}

The authors would express gratitude to Department of Business Management ITS for the funding under the research grant, namely "Penelitian Dana Departemen ITS Tahun 2020"

\section{REFERENCES}

[1] Kahfi, K. (2019, December 16th 2019). Circular Economy Going Around in Circles, Experts Say. The Jakarta Post

[2] Badan Perencanaan Pembangunan Nasional. 2004. Tata cara Perencanaan Pengembangan Kawasan Untuk Percepatan Pembangunan Daerah. Direktorat Pengembangan Kawasan Khusus dan Tertinggal. Jakarta: Bappenas.

[3] Moore, J. F. (1993). Predators and prey: a new ecology of competition. Harvard business review, 71(3), 75-86.

[4] Osterwalder, A., \& Pigneur, Y. (2010). Business model generation: a handbook for visionaries, game changers, and challengers: John Wiley \& Sons.

[5] Rosing, K., Frese, M., \& Bausch, A. (2011). Explaining the heterogeneity of the leadershipinnovation relationship: Ambidextrous leadership. The leadership quarterly, 22(5), 956-974

[6] Looser, S., \& Wehrmeyer, W. (2015). Stakeholder mapping of CSR in Switzerland. Social Responsibility Journal.

[7] Nandonde, F. A. (2019). A PESTLE analysis of international retailing in the East African Community. Global Business and Organizational Excellence, 38(4), 54-61. 